
Multidisciplinary
SCIENTIFIC JOURNAL

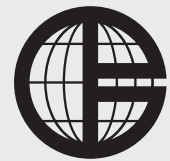
Multidisciplinarni
OF MARITIME RESEARCH
University of Rijeka
znanstveni časopis
POMORSTVO
FACULTY OF MARITIME STUDIES

\title{
Comparative analysis and estimation of amounts of exhaust gas waste heat from the Tier III-compliant dual-fuel low-speed marine main engines
}

\author{
Piotr Kamil Korlak \\ Doctoral School of the Maritime University of Szczecin, 1-2 Wały Chrobrego Str., 70-500 Szczecin, Poland, e-mail: 27901@s.am.szczecin.pl
}

\section{ABSTRACT}

Existing and future IMO restrictions on emission of harmful substances contained in exhaust gas have introduced an obligation to implement technical solutions to reduce $\mathrm{NO}_{\mathrm{X}}, \mathrm{SO}_{\mathrm{X}}$ and $\mathrm{CO}_{2}$ emissions. Reduction in $\mathrm{NO}_{\mathrm{x}}$ and $\mathrm{SO}_{\mathrm{x}}$ emissions has been achieved by systems (i.e. SCR and EGR) ensuring Tier III-compliant exhaust gas composition. SCR and EGR systems have also affected the amount of exhaust gas waste heat. Therefore reduction in $\mathrm{CO}_{2}$ emissions has mostly been dependent on available amount of exhaust gas waste heat to produce electricity using waste heat recovery generator unit instead of medium-speed diesel generating set. Comparative analysis of amounts of exhaust gas waste heat in LNG and MGO modes under ISO ambient conditions has been carried out with particular emphasis on the impact of different variants of SCR and EGR systems. Formulae to estimate the amounts of exhaust gas waste heat have been determined using least squares method.

\section{ARTICLE INFO}

Preliminary communication

Received 12 April 2021

Accepted 28 May 2021

\author{
Key words: \\ Low-speed engine \\ Dual-fuel \\ LNG \\ Waste heat \\ Tier III \\ EEDI \\ SCR \\ EGR
}

\section{Introduction}

Chapter 4 of the MARPOL Annex VI, put into effect in July 2011, obliged shipowners to use technical solutions to reduce carbon dioxide $\left(\mathrm{CO}_{2}\right)$ emission. The regulations in force since January 2013 have imposed an obligation to introduce the Ship Energy Efficiency Management Plan (SEEMP). All vessels over 400 GT built as from January 2013 are subject to the Energy Efficiency Design Index (EEDI). The standard puts a cap on the amount of $\mathrm{CO}_{2}$ allowed per unit of transport work. Until 2025, ships are required to achieve a 30-percent reduction in their $\mathrm{CO}_{2}$ emissions compared with the average emissions of ships built between 1999 and 2009. The EEDI value calculated in accordance with the procedure shown in Fig. 1 must be less than or equal to the value required for the type and size of ship [1, 9]. In addition, according to the findings of the $75^{\text {th }}$ session of the Marine Environment Protection Committee (MEPC), from 2023 all in-service ships are planned to be subject to minimum energy efficiency stand- ards, as defined by the EEDI-equivalent Energy Efficiency Existing Ship Index (EEXI) [4].

The necessity for the reduction in $\mathrm{CO}_{2}$ emissions from ships means that seeking ways for deep waste heat recovery to produce electrical energy has increased in importance, because, inter alia, the production of heating steam in waste heat boilers does not make it possible to lower the EEDI value (Fig. 1). Furthermore, the heating steam requirement is significantly reduced in the case of the use of low-sulphur fuels. However, $\mathrm{CO}_{2}$ is not the only substance restricted by MARPOL Annex VI which regulates the amount and parameters of waste heat [5]. The existing IMO limits on nitrogen oxide $\mathrm{NO}_{\mathrm{x}}$ emissions, and fuel sulphur content, were shown in Fig. 2.

Continually decreasing and territorially expanding restrictions also apply to nitrogen oxides $\mathrm{NO}_{\mathrm{x}}$ and sulphur oxides $\mathrm{SO}_{\mathrm{x}}$. They are strictly defined in the current IMO Tier II and Tier III standards. Tier II is global, while the range of the more restrictive Tier III is currently limited to 


\section{Attained EEDI: Calculation formula}
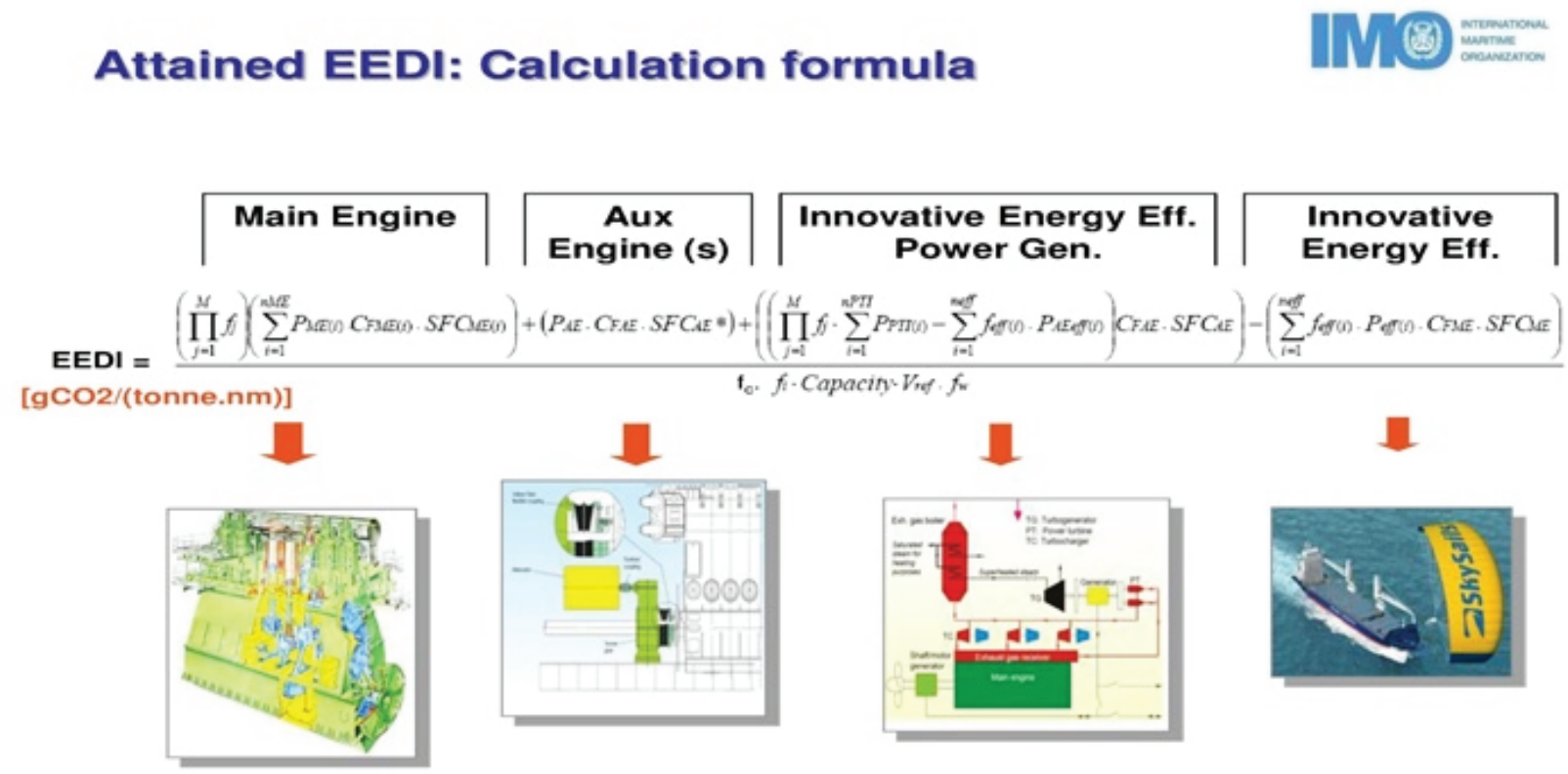

Boilers are excluded from EEDI

Fig. 1 Energy Efficiency Design Index EEDI [1]
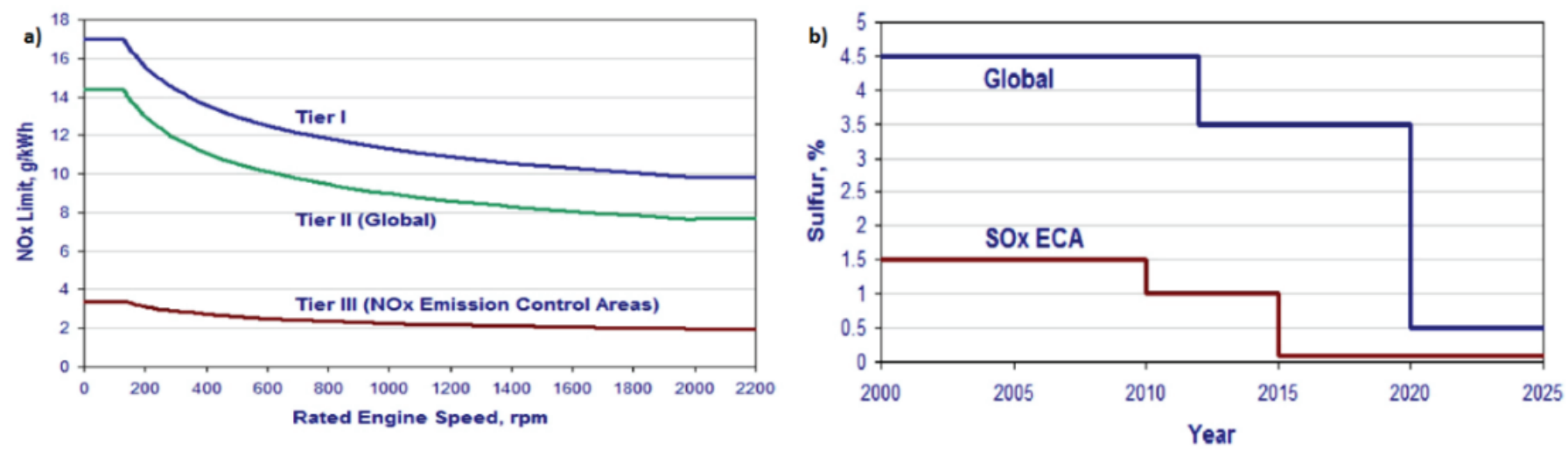

Fig. 2 MARPOL Annex VI limits of: a) $\mathrm{NO}_{\mathrm{x}}$ emission, b) fuel sulphur content [2]

the Baltic and North Sea, and the parts of North American coastal waters below $60^{\circ} \mathrm{N}$ (Fig. 3). The sulphur content reduction to $0.1 \%$ met by Marine Gas Oil (MGO) has also applied in the territorial seas of the European Union Member States [3, 9].

Ships designed for global operation must be equipped with their main engines fully compliant with the strictest Tier III emission standards, which manufacturers are no longer able to meet except by construction changes. The greatest impact on harmful substance emission emanates from the combustion temperature, an increase in which results in the more-efficient combustion of the air-fuel mixture in the combustion chamber. This is associated with the lower emission of particulate matters (mostly soot and hydrocarbons) but with a simultaneous and un- acceptable increase in the discharge of $\mathrm{NO}_{\mathrm{x}}$. The necessity to overcome this dilemma has led to the development of selective catalytic reduction (SCR) and exhaust gas recirculation (EGR) systems $[2,15]$. Tangible benefits are also accrued by the use of liquified natural gas (LNG) as a marine fuel, which, in comparison with distillate and residual marine fuels, makes it possible to reduce the emission of $\mathrm{SO}_{\mathrm{X}}$ and particulate matters up to $99 \%$, of $\mathrm{NO}_{\mathrm{X}}$ up to $85 \%$, and of $\mathrm{CO}_{2}$ up to $20 \%$ [8].

The aim of this paper is to carry out heat balance of selected dual-fuel low-speed marine main engine, a comparative analysis of amount of exhaust gas waste heat with particular emphasis on the impact of the available Tier III-compliant systems, and the determination of formulae allowing the estimating of amount of exhaust 


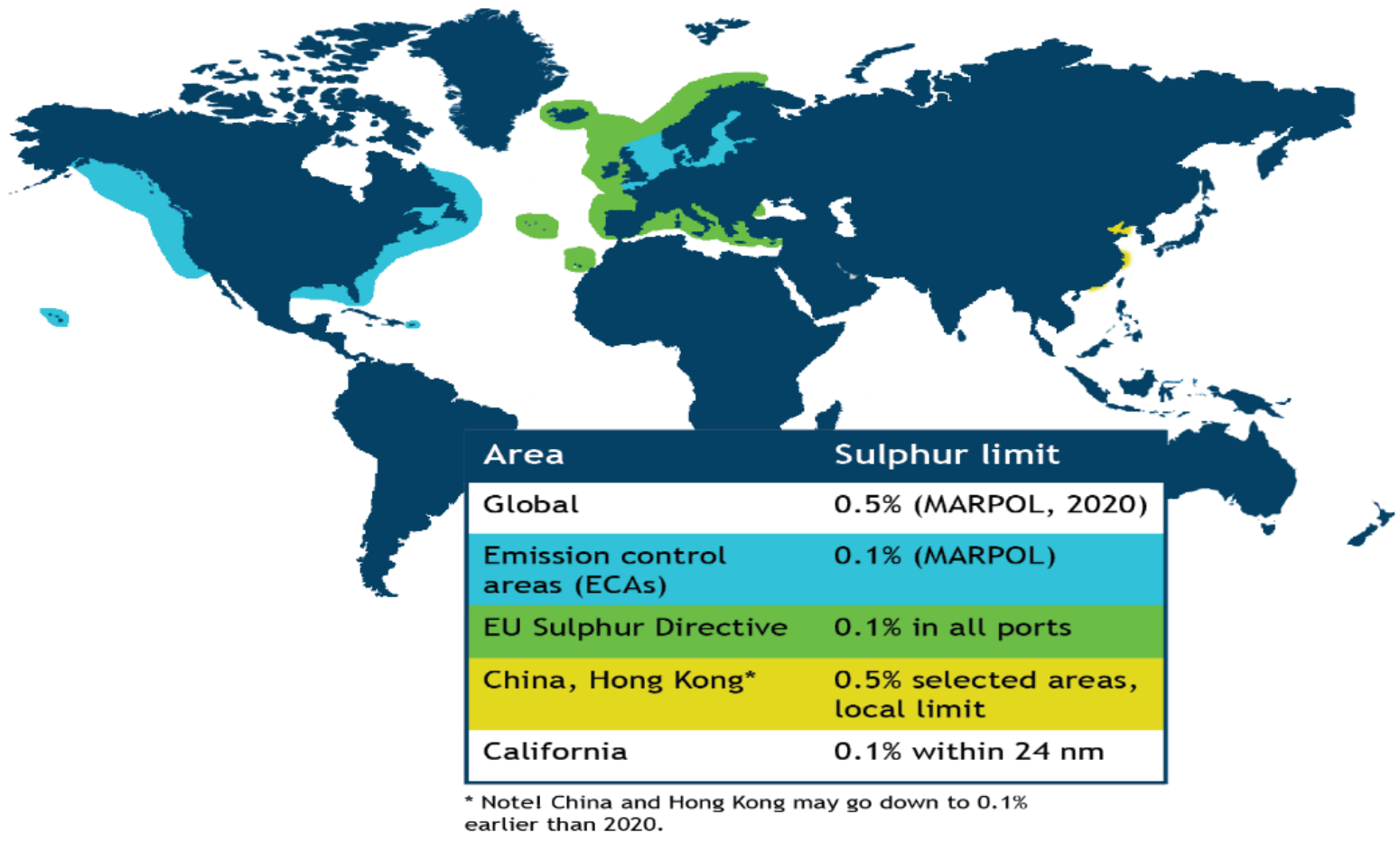

Fig. 3 Sulphur emission control areas [3]

gas waste heat under ISO ambient conditions for the full range of load. The least-squares method was used for the calculations based on the performance parameters obtained from computer-aided main engine selection software (MAN CEAS Engine Calculations and WinGD General Technical Data).

\section{Heat balance of dual-fuel low-speed main engine}

Heat balance results from the heat energy supplied to the main engine into the useful heat energy equivalent to the brake power and the sum of heat losses. The percentage of all components in relation to the supplied heat energy is fixed to make the heat balance more comprehensive [20].

Heat balance is always maintained at a constant load for maximum continuous rating (MCR) parameters after the main engine has reached thermal equilibrium. The results are presented analytically, and in the form of a Sankey diagram. The heat balance results allow the determining of the impact of various factors on the main engine's operation, on the ways of increasing its efficiency, and on selecting auxiliary systems with the appropriate characteristics [20].

Formula of the heat balance of internal combustion engine [20]:

$\dot{Q}_{T}=\dot{Q}_{e}+\sum \dot{Q}_{L}=\dot{Q}_{e}+\left(\dot{Q}_{c o}+\dot{Q}_{c w}+\dot{Q}_{c a}+\dot{Q}_{g}+\dot{Q}_{r}\right)$ where:

$\dot{Q}_{T}[\mathrm{~kW}]$ - supplied heat energy

$\dot{Q}_{e}=P_{B}[\mathrm{~kW}]-$ useful heat energy equivalent to engine brake power

$\Sigma \dot{Q}_{L}[\mathrm{~kW}]$ - sum of the heat losses comprising to the following:

$\dot{Q}_{c o}[\mathrm{~kW}]$ - heat loss of the lubrication oil

$\dot{Q}_{c w}[\mathrm{~kW}]$ - heat loss of the cooling water

$\dot{Q}_{c a}[\mathrm{~kW}]$ - heat loss of the scavenge air

$\dot{Q}_{g}[\mathrm{~kW}]$ - heat loss of the exhaust gas

$\dot{Q}_{r}[\mathrm{~kW}]$ - heat loss of the radiation

and [20]:

$\dot{Q}_{T}=\frac{P_{B}}{\eta_{o}}=\frac{P_{B} \cdot\left(L H V_{F O} \cdot S F O C_{F O}+L H V_{L N G} \cdot S G C_{L N G}\right)}{3,600}$

where:

$\eta_{o}$ - overall energy efficiency

$L H V_{F O}[\mathrm{~kJ} / \mathrm{kg}]$ - lower heating value of the marine fuel oil

$S F O C_{F O}[\mathrm{~g} / \mathrm{kWh}]$ - specific marine fuel oil consumption

$L H V_{L N G}[\mathrm{~kJ} / \mathrm{kg}]$ - lower heating value of the natural gas, if necessary

$S G C_{L N G}[\mathrm{~g} / \mathrm{kWh}]$ - specific natural gas consumption, if necessary 
and [15]:

$\dot{Q}_{g}=\dot{m}_{g} \cdot C_{p} \cdot\left(T_{g}-T_{a}\right)$

where:

$\dot{m}_{g}[\mathrm{~kg} / \mathrm{h}]$ - mass flow of the exhaust gas

$C_{p}[\mathrm{~kJ} / \mathrm{kg} \cdot \mathrm{K}]$ - specific heat of the exhaust gas

$T_{g}[\mathrm{~K}]$ - exhaust gas temperature

$T_{a}[\mathrm{~K}]$ - ambient temperature

An illustrative heat balance was carried out for Tier IIIcompliant MAN 12G95ME-C10.5-GI-LPSCR operating at MCR load under ISO ambient conditions in LNG and MGO mode. Basic technical data of this engine were shown in Tab. 1.

Values shown in Sankey diagram (Fig. 4) were determined according to formulae $(1 \div 3)$ and data generated in CEAS Engine Data Report.

The Sankey diagram (Fig. 4) shows that $52.38 \%$ of the supplied energy was converted into brake power, the rest being losses. Therefore, potentially large amounts of energy could be recovered, but this was severely hampered by the relatively low temperature of the energy carriers. Conventional waste heat recovery systems rely on waste heat of exhaust gas, which has by far the highest temperature $[5,7]$. According to the MAN Energy Systems, the ap-
Tab. 1 Basic technical data of MAN12G95ME-C10.5-GI-LPSCR operating at MCR load under ISO ambient conditions [13]

\begin{tabular}{|c|c|}
\hline Parameter & Value \\
\hline MCR brake power & $82,440 \mathrm{~kW}$ \\
\hline MCR speed & $80 \mathrm{rpm}$ \\
\hline Mean effective pressure & $21 \mathrm{bar}$ \\
\hline Piston bore & $95 \mathrm{~cm}$ \\
\hline Piston stroke & $346 \mathrm{~cm}$ \\
\hline Fuel type & LNG + pilot oil \\
\hline Specific gas consumption & $134.6 \mathrm{~g} / \mathrm{kWh}$ \\
\hline Specific pilot oil consumption & $2.43 \mathrm{~g} / \mathrm{kWh}$ \\
\hline $\mathrm{NO}_{\mathrm{x}}$ emission compliance & Tier III \\
\hline Tier III-compliant system & $\begin{array}{c}\text { Low-pressure selective catalytic } \\
\text { reduction (LPSCR) }\end{array}$ \\
\hline
\end{tabular}

plication of a waste heat recovery system facilitates the generation of electrical energy in the amount of $3 \div 11 \%$ of main engine brake power (Tab. 2), making it possible to avoid the operation of the some diesel generating sets [10]. However, the exhaust gas of main engines equipped with SCR and EGR systems differ in both mass flow and temperature, which implies differences in waste heat. These are discussed in detail later in this paper.

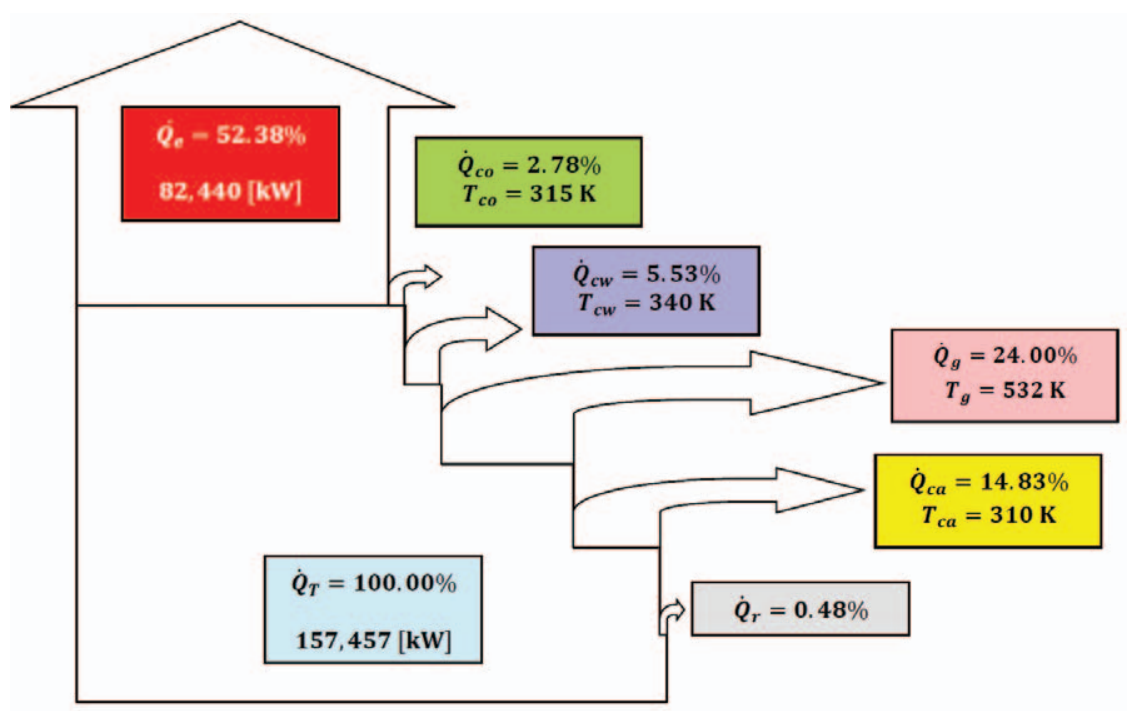

Fig. 4 Sankey diagram of the MAN 12G95ME-C10.5-GI-LPSCR operating in LNG mode at MCR load under ISO ambient conditions, own study on basis [13]

Tab. 2 Comparison of the waste heat recovery generator units [10]

\begin{tabular}{|c|c|c|}
\hline Man engine brake power & $\begin{array}{c}\text { Dedicated type of generator unit for } \\
\text { waste heat recovery }\end{array}$ & $\begin{array}{c}\text { Possible electrical energy generation as } \\
\text { a percent of man engine brake power }\end{array}$ \\
\hline$>25,000[\mathrm{~kW}]$ & Combined steam turbine and gas turbine & $8.00 \div 11.00 \%$ \\
\hline $15,000 \div 25,000[\mathrm{~kW}]$ & Steam turbine or gas turbine & $4.00 \div 8.00 \%$ \\
\hline$<15,000[\mathrm{~kW}]$ & Gas turbine & $3.00 \div 5.00 \%$ \\
\hline
\end{tabular}


Tab. 3 Comparison of the availability of Tier III-compliant systems $[12,17]$

\begin{tabular}{|c|c|c|}
\hline \multirow{2}{*}{ Tier III-compliant system } & MAN & \multicolumn{2}{|c|}{ WinGD } \\
\cline { 2 - 3 } & \multicolumn{2}{|c|}{ All engines } \\
\hline LPSCR (Low-pressure selective catalytic reduction) & \multicolumn{2}{|c|}{ for } \\
\hline HPSCR (High-pressure selective catalytic reduction) & $\begin{array}{c}\text { Engines equipped with no more than } 8 \mathrm{cylinders} \\
\text { EGRTC (Exhaust gas recirculation turbocharger cut-out) }\end{array}$ & $\begin{array}{c}\text { Engines equipped with piston bore } \geq 80 \mathrm{~cm} \\
\text { and at least 2 turbochargers }\end{array}$ \\
\hline EcoEGR (Eco Exhaust gas recirculation) & \multicolumn{2}{|c|}{$\begin{array}{c}\text { All engines } \\
\text { Unavalaible }\end{array}$} \\
\hline EGRBP (Exhaust gas recirculation by-pass) & $\begin{array}{c}\text { Engines equipped with piston bore } \leq 70 \mathrm{~cm} \\
\text { and only } 1 \text { turbocharger }\end{array}$ \\
\hline
\end{tabular}

\section{Available Tier III-compliant systems}

MAN and WinGD low-speed marine main engines are equipped with systems mentioned in Tab. 3 facilitating the obtaining of exhaust gas composition fully compliant with Tier III-emission standards, among which both SCR variants are characterised by the slightly higher effectiveness of the $\mathrm{NO}_{\mathrm{x}}$ reduction $[12,17]$. A comparison of the effectiveness of the $\mathrm{NO}_{\mathrm{x}}$ reductions is shown in Fig. 5.

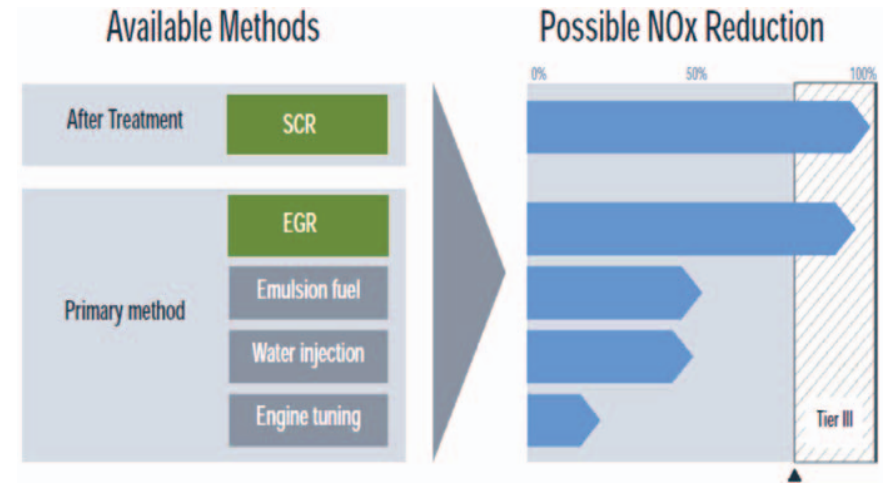

Fig. 5 Comparison of the $\mathrm{NO}_{\mathrm{x}}$ reduction effectivensess [12]

\subsection{Selective catalytic reduction (SCR)}

Selective catalytic reduction (SCR) is based on air-fuel mixture combustion in the range $300 \div 400{ }^{\circ} \mathrm{C}$ temperatures, i.e. optimum values for required chemical reactions involving ammonia $\mathrm{NH}_{3}$. A $40 \%$ urea $\mathrm{CO}\left(\mathrm{NH}_{2}\right)_{2}$ solution, decomposing into ammonia $\mathrm{NH}_{3}$ and carbon dioxide $\mathrm{CO}_{2}$, is injected into the catalysator, through which exhaust gases are passed. $\mathrm{NH}_{3}$ then reduces the $\mathrm{NO}_{\mathrm{x}}$ into inert molecular nitrogen $\mathrm{N}_{2}$ and water vapour in a series of chemical reactions. Moreover, SCR systems reduce the hydrocarbon content due to their oxidation into non-toxic compounds in the oxodation reactor [6]. The SCR schematic diagram and the occuring chemical reactions are shown in Fig. 6.

The advantages of SCR systems include the very high (above 90\%) efficiency of the $\mathrm{NO}_{\mathrm{x}}$ after treatment of exhaust gas, the lower consumption of energy needed to supply than in other methods, and no waste from the process [12].

The disadvantages of SCR systems are their high costs of the application of catalysators (platinum, vanadium, or titanium), their low resistance to heavy-metal contamination, and propensity to deactivation by $\mathrm{SO}_{\mathrm{x}}$, as well as the

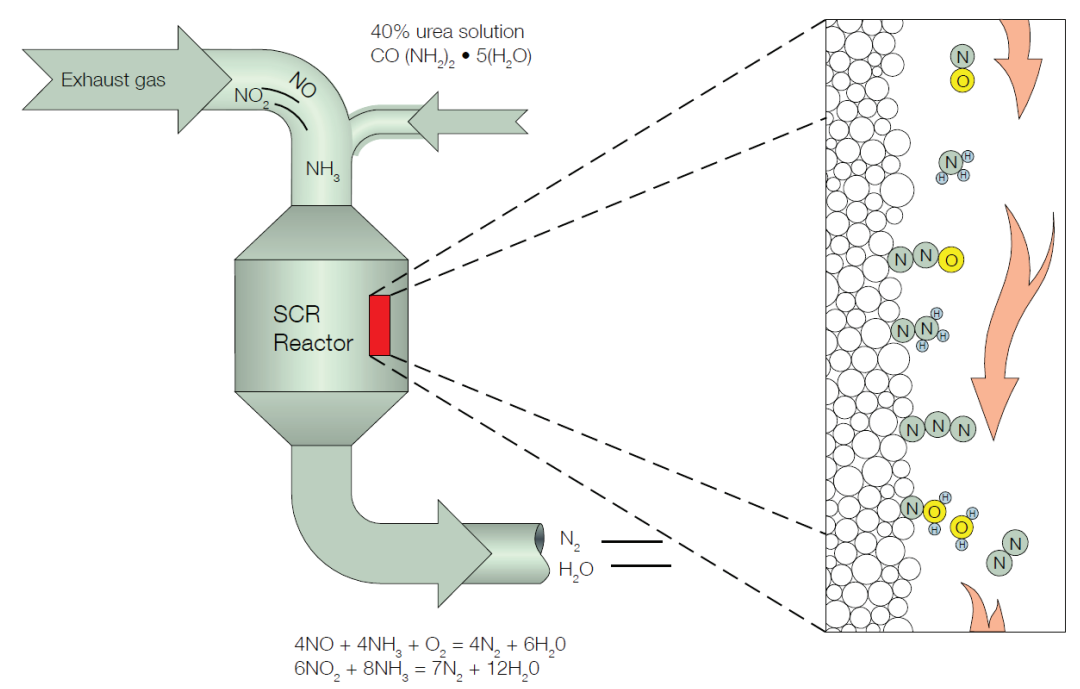

Fig. 6 SCR schematic diagram [12] 


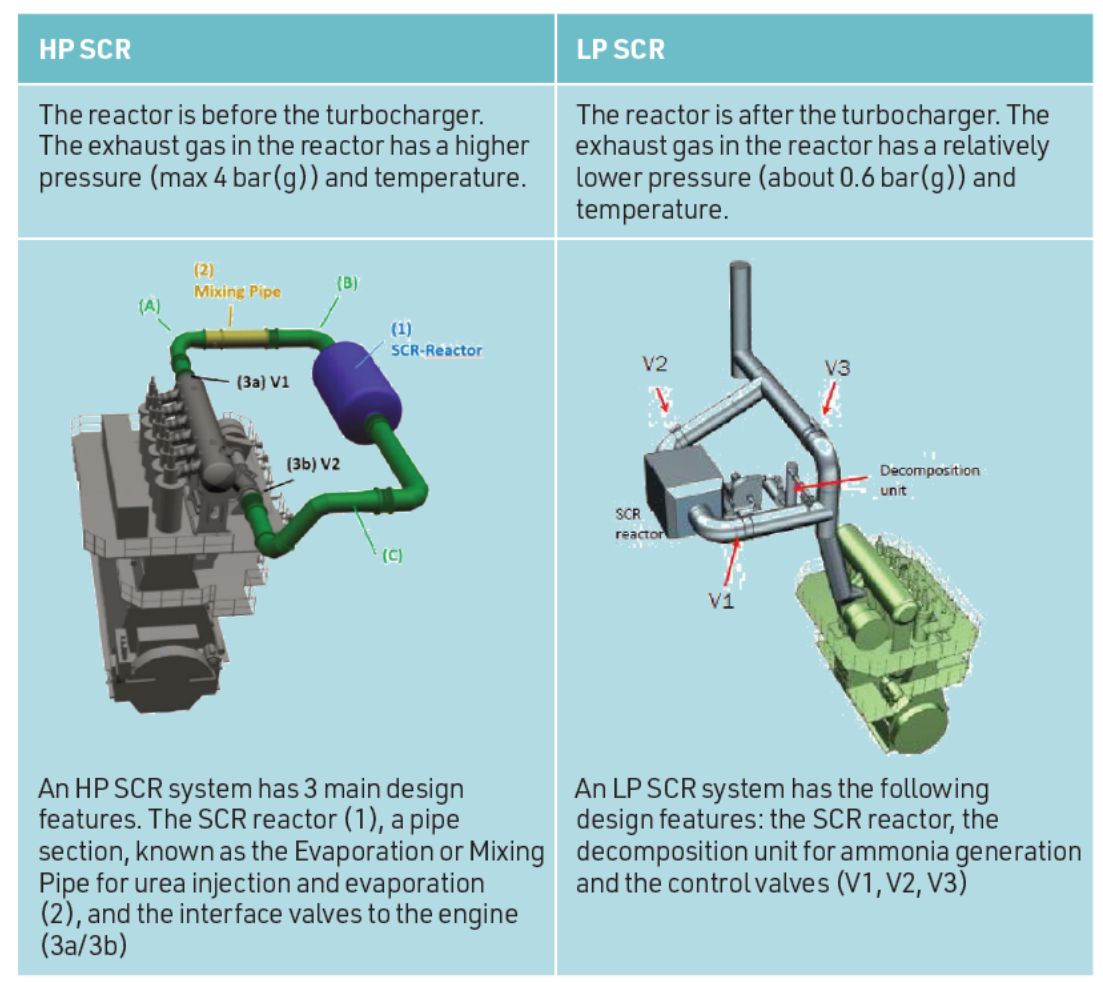

Fig. 7 Comparison of the reactors position [19]

Tab. 4 Comparison of the LPSCR and HPSCR key characteristics [19]

\begin{tabular}{|c|c|c|}
\hline Key characteristics & LPSCR & HPSCR \\
\hline Reactor position & $\begin{array}{c}\text { After turbocharger (outside engine room) } \rightarrow \text { lower } \\
\text { pressure and temperature of exhaust gas }\end{array}$ & $\begin{array}{c}\text { Before turbocharger (inside engine room) } \rightarrow \text { higher } \\
\text { pressure and temperature of exhaust gas }\end{array}$ \\
\hline Ammonia generation & $\begin{array}{c}\text { Through ammonia generation using a fuel oil burner } \\
\text { Urea injected into the mixed piping with high } \\
\text { temperature exhaust gas, no energy consumption }\end{array}$ \\
\hline $\begin{array}{c}\text { Minimum working } \\
\text { temperature }\end{array}$ & $\begin{array}{c}\text { Exhaust gas after turbocharger } 230 ~ \\
{ }^{\circ} \mathrm{C} \text { for fuel } \\
<0.1 \% \mathrm{~S}\end{array}$ & $\begin{array}{c}\text { Exhaust gas before turbocharger } 310{ }^{\circ} \mathrm{C} \\
\text { for fuel }<0.1 \% \mathrm{~S}\end{array}$ \\
\hline Fuel penalties & $\begin{array}{c}\leq 3 \mathrm{~g} / \mathrm{kWh} \text { between } 25 \div 50 \% \text { of engine MCR load } \\
\leq 2 \mathrm{~g} / \mathrm{kWh} \text { between } 50 \div 80 \% \text { of engine MCR load }\end{array}$ & $\leq 3 \mathrm{~g} / \mathrm{kWh}$ between $25 \div 40 \%$ of engine MCR load \\
Engine interfaces & No engine modification & $\begin{array}{c}\text { Engine mechanical modifications: } \\
\text { Exhaust gas manifold } \\
\text { Engine gallery }\end{array}$ \\
\hline
\end{tabular}

use of corrosive $\mathrm{NH}_{3}$ and the necessity for exhaust-gas pretreatment due to the presence of volatile ash, causing a decrease in the process's efficiency. A system controlling the amount of $\mathrm{NH}_{3}$ fed in, depending on the flow of exhaust gas, i.e. the main-engine load, is also required [12].

SCR systems are available in low- and high-pressure variants, which are subject to the position of the reactor in relation to the turbocharger (Fig. 7), and thus the pressure and temperature of exhaust gas $[9,11]$. Both variants of the SCR systems were shown in Fig. 7.

There are several differences between both SCR system variants, among which the most important were contained in Tab. 4 [19].

\subsection{Exhaust gas recirculation}

Exhaust gas recirculation (EGR) consists of the returning of a certain volume of exhaust gas (usually $30 \div 40 \%$ of total) to the engine's filling unit, causing an increase in the content of $\mathrm{CO}_{2}$ and water vapour in a fresh charge of air, which reduces the average combustion temperature, due to the greater specific-heat capacity.

The reduction in the molecular oxygen $\mathrm{O}_{2}$ content in the air hinders the formation of $\mathrm{NO}_{\mathrm{x}}$, but decreases the combustion efficiency at lower temperatures, and promotes particulate-matter emission due to the lower combustion efficiency $[6,16]$. 
Tab. 5 Comparison of the EGR systems key characterictics [14]

\begin{tabular}{|c|c|c|c|}
\hline \multirow{2}{*}{ Key characteristics } & EGRTC & EGRBP & EcoEGR \\
\cline { 2 - 4 } & $\begin{array}{c}\text { Cut-out valve between exhaust } \\
\text { receiver and turbocharger rotor }\end{array}$ & $\begin{array}{c}\text { Exhaust gas by-pass between } \\
\text { exhaust receiver and turbocharger }\end{array}$ & $\begin{array}{c}\text { Optimized version of EGRBP, } \\
\text { operates with only about 15\% } \\
\text { recirculation }\end{array}$ \\
\hline
\end{tabular}

a) EGR - By-pass matching

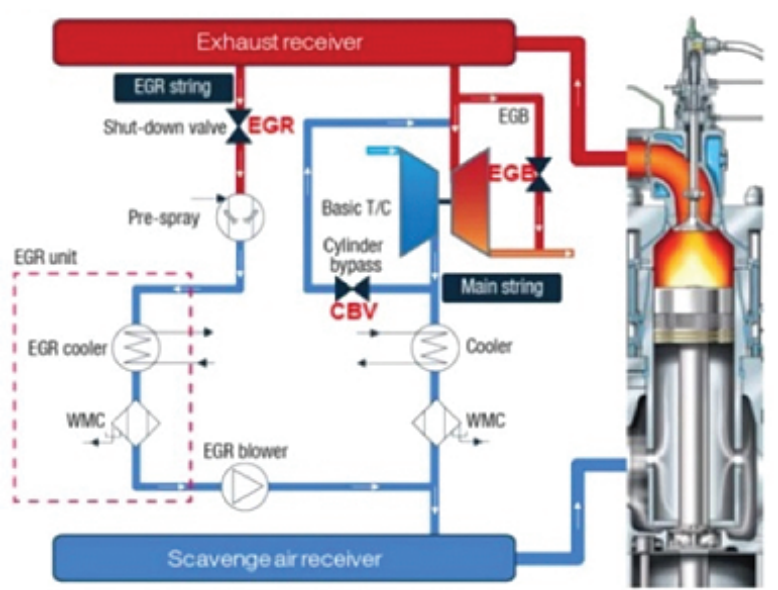

b) EGR - Cut-out matching

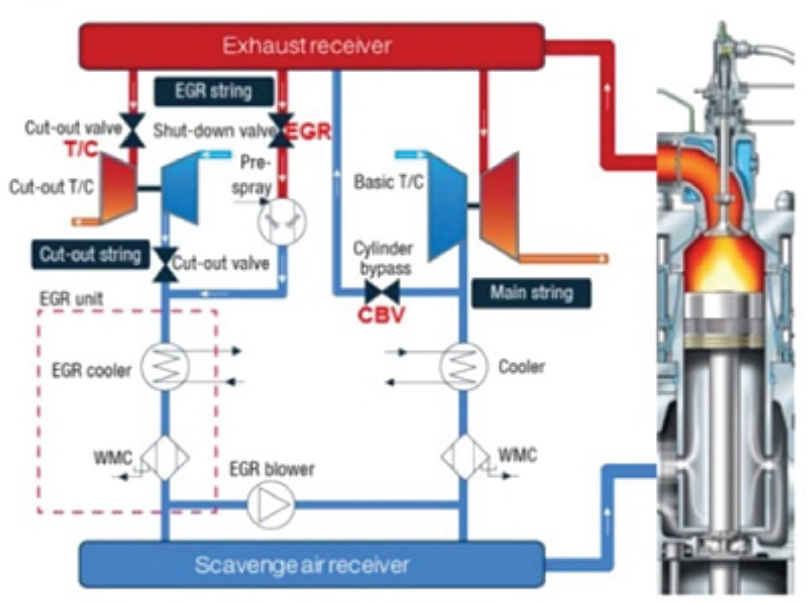

Fig. 8 Schematic diagrams of different variants of EGR systems: a) EGRBP, b) EGRTC [2]

The advantages of EGR systems are the high efficiency $\mathrm{NO}_{\mathrm{x}}$ after-treatment of exhaust gas, and the otherwise unachievable reduction in exhaust-gas emissions, their relatively simple design, and there being no necessity for additional agents to be involved in the process [12].

The main disadvantages of EGR systems include a decrease in the average combustion temperature of the airfuel mixture, which implies a drop in the efficiency of this process, and thus higher specific fuel consumption $g_{e^{\prime}}$ so increasing the operating costs of the engine and the whole ship [12].

EGR systems are available in several variants, each adapted to the number of turbochargers and piston diameters employed (Fig. 8). The key characteristics of EGR systems are presented in Tab. 5 [14].

\section{Comparative analysis of amounts of exhaust gas waste heat from dual-fuel low-speed marine main engines}

The amounts of exhaust gas waste heat were shown separately for all types of Tier III-compliant MAN and WinGD dual-fuel low-speed main engines operating at the MCR load under ISO-ambient conditions in the LNG (Tab. 6) and MGO modes (Tab. 7). The following annotations are referred to in both Tab. 6 and Tab. 7 .

The percentage share of exhaust gas waste heat in the total energy supplied by LNG to the MAN 8G95ME-C10.5GI equipped with various SCR and EGR systems operating at the MCR load under ISO-ambient conditions was presented in Fig. 9.

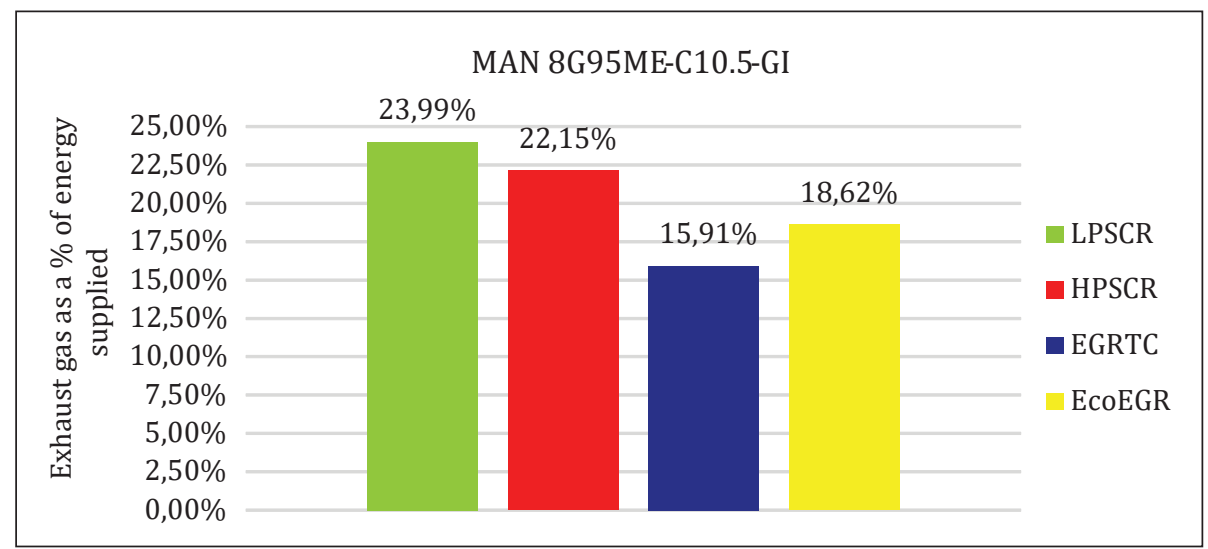

Fig. 9 Exhaust gas waste heat as a \% of total energy supplied in LNG [own study] 
Tab. 6 Amounts of exhaust gas waste heat from Tier III-compliant low-speed engines in LNG mode, own study on basis [13, 18]

\begin{tabular}{|c|c|c|c|c|}
\hline \multirow{2}{*}{\multicolumn{2}{|c|}{$\begin{array}{c}\text { Manufacturer } \\
\text { Engine type }\end{array}$}} & \multicolumn{2}{|c|}{ MAN } & WinGD \\
\hline & & $G$ & $\mathrm{~S}$ & $\mathrm{X}$ \\
\hline \multicolumn{2}{|c|}{ Piston bore } & $45 \div 95 \mathrm{~cm}$ & $35 \div 70 \mathrm{~cm}$ & $40 \div 92 \mathrm{~cm}$ \\
\hline \multicolumn{2}{|c|}{ Cylinder number } & $5 \div 12$ & $5 \div 8$ & $5 \div 12$ \\
\hline \multicolumn{2}{|c|}{ MCR brake power } & $6,950 \div 82,440 \mathrm{~kW}$ & $4,350 \div 27,440 \mathrm{~kW}$ & $2,775 \div 63,840 \mathrm{~kW}$ \\
\hline \multicolumn{2}{|c|}{ MCR speed } & $80 \div 111 \mathrm{rpm}$ & $91 \div 167 \mathrm{rpm}$ & $80 \div 146 \mathrm{rpm}$ \\
\hline \multicolumn{2}{|c|}{ Fuel type } & \multicolumn{3}{|c|}{ LNG + pilot oil } \\
\hline Waste heat & $\begin{array}{c}\text { Tier III-compliant } \\
\text { Technology }\end{array}$ & \multicolumn{3}{|c|}{ Temperature } \\
\hline \multirow{12}{*}{ Exhaust gas } & \multirow{3}{*}{ LPSCR } & $24.00 \div 25.70 \%$ & $24.80 \div 27.60 \%$ & $22.30 \div 23.40 \%$ \\
\hline & & $17.20 \div 157.70 \mathrm{~kg} / \mathrm{s}$ & $10.60 \div 58.70 \mathrm{~kg} / \mathrm{s}$ & $12.70 \div 143.10 \mathrm{~kg} / \mathrm{s}$ \\
\hline & & $524 \div 542 \mathrm{~K}$ & $536 \div 542 \mathrm{~K}$ & $500 \div 504 \mathrm{~K}$ \\
\hline & HPSCR $^{1)}$ & $22.10 \div 23.90 \%$ & $24.20 \div 27.10 \%$ & \\
\hline & \multirow[t]{2}{*}{ EGRBP $^{2)}$} & $14.90 \div 53.70 \mathrm{~kg} / \mathrm{s}$ & $9.10 \div 50.40 \mathrm{~kg} / \mathrm{s}$ & \\
\hline & & $510 \div 512 \mathrm{~K}$ & $507 \div 511 \mathrm{~K}$ & \\
\hline & \multirow{3}{*}{ EcoEGR } & $18.40 \div 19.40 \%$ & $17.10 \div 19.50 \%$ & \\
\hline & & $14.70 \div 134.10 \mathrm{~kg} / \mathrm{s}$ & $8.70 \div 49.90 \mathrm{~kg} / \mathrm{s}$ & \\
\hline & & $514 \div 517 \mathrm{~K}$ & $509 \div 511 \mathrm{~K}$ & \\
\hline & \multirow{3}{*}{ EGRTC $^{3)}$} & $16.80 \div 17.30 \%$ & & \\
\hline & & $39.20 \div 112.10 \mathrm{~kg} / \mathrm{s}$ & & \\
\hline & & $512 \div 515 \mathrm{~K}$ & & \\
\hline
\end{tabular}

Tab. 7 Amounts of exhaust gas waste heat from Tier III-compliant low-speed engines in MG0 mode, own study on basis [13, 18]

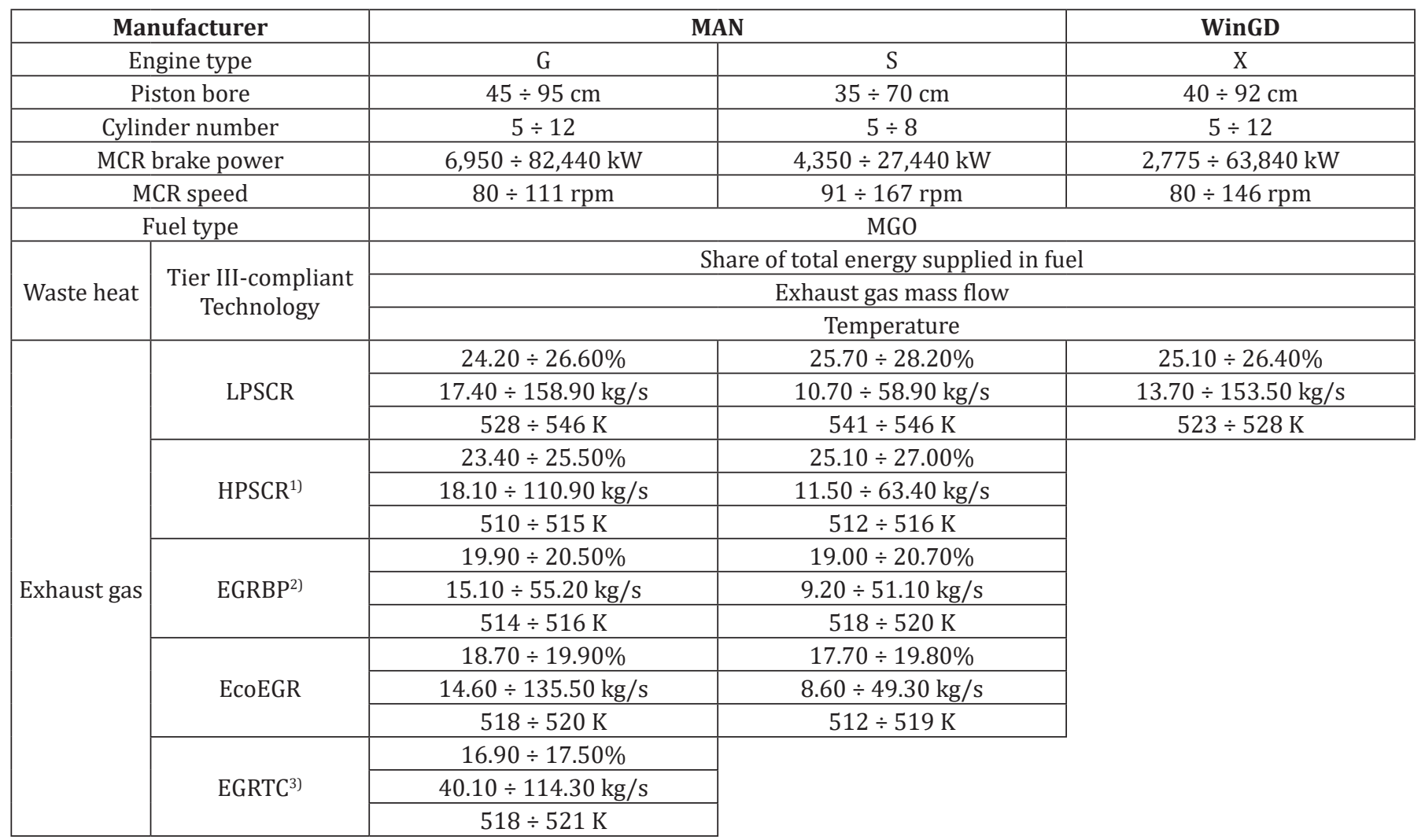

1) Available only for MAN engines equipped with no more than 8 cylinders; ${ }^{2)}$ Avalaible only for MAN engines equipped with piston bore $\leq 70 \mathrm{~cm}$;

3) Avalaible only for MAN engines equipped with piston bore $\geq 80 \mathrm{~cm}$ 
The following findings were set out based on a comparison of the data contained in Tab. 6 and Tab. 7.

- The largest amounts of exhaust gas waste heat are contained in engines equipped with LPSCR (low-pressure selective catalytic reduction) systems, due to their highest by far exhaust gas temperature, and the value of the product of its flow and temperature.

- Engines equipped with HPSCR systems are characterised by the greatest exhaust gas flow for a given brake power, but their lower temperature reduces the amount of exhaust gas waste heat by $0.8 \div 2.5$ percentage points in comparison with LPSCR.

- The exhaust gases in EGR systems are subjected to cooling, due to the necessity of its volume reduction [15]. Therefore an additional loss of exhaust gas cooling $(15.5 \div 17.5 \%$ of the energy supplied in the fuel) is generated in the heat balance of engines equipped with EGR systems operating at the MCR load under ISO ambient conditions.

- All variants of EGR systems reduce amount of exhaust gas waste-heat by $22.5 \div 33.9 \%$ in comparison with LPSCR, due to their reusing a significant part of the ex- haust gases (up to $40 \%$ ) in the engine's filling unit, thus reducing the emitted exhaust gas mass flow.

- The volume of the exhaust gas waste heat and emitted exhaust gas mass flow increases with the functioning of the engine load, reaching the maximum at the MCR load point.

Percentage share of exhaust gas waste heat from all available dual-fuel low-speed engines under ISO ambient conditions in relation to total energy supplied in LNG was presented in Fig. 10.

In analysing the data contained in Fig. 10, it may be stated that the percentage share of exhaust gas waste heat in the engine heat balance decreases with the engine load, reaching its minimum at the MCR load point. The proportion of the exhaust-gas waste heat in the engine-heat balance for $25 \%$ of the MCR load is on average $6.5 \div 7.2 \%$ percentage points higher than the value corresponding to the MCR load.

Temperature of exhaust gas of all available LNG-fuelled low-speed engines in the function of the engine load was presented in Fig. 11.

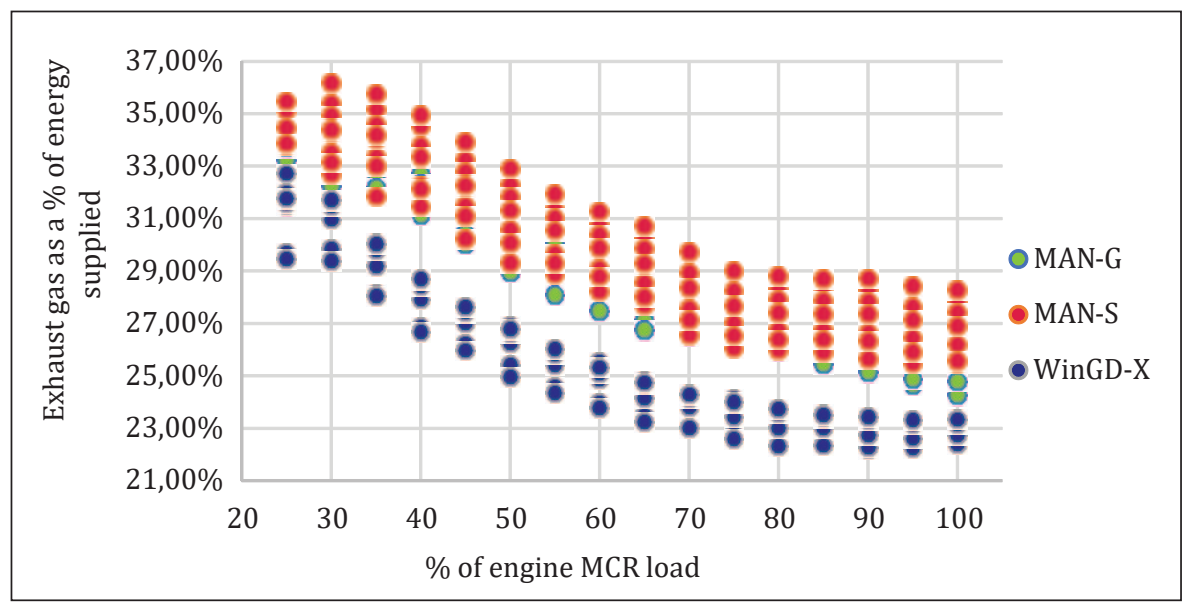

Fig. 10 Exhaust gas waste heat as a \% of total energy supplied in LNG to all available low-speed engines [own study]

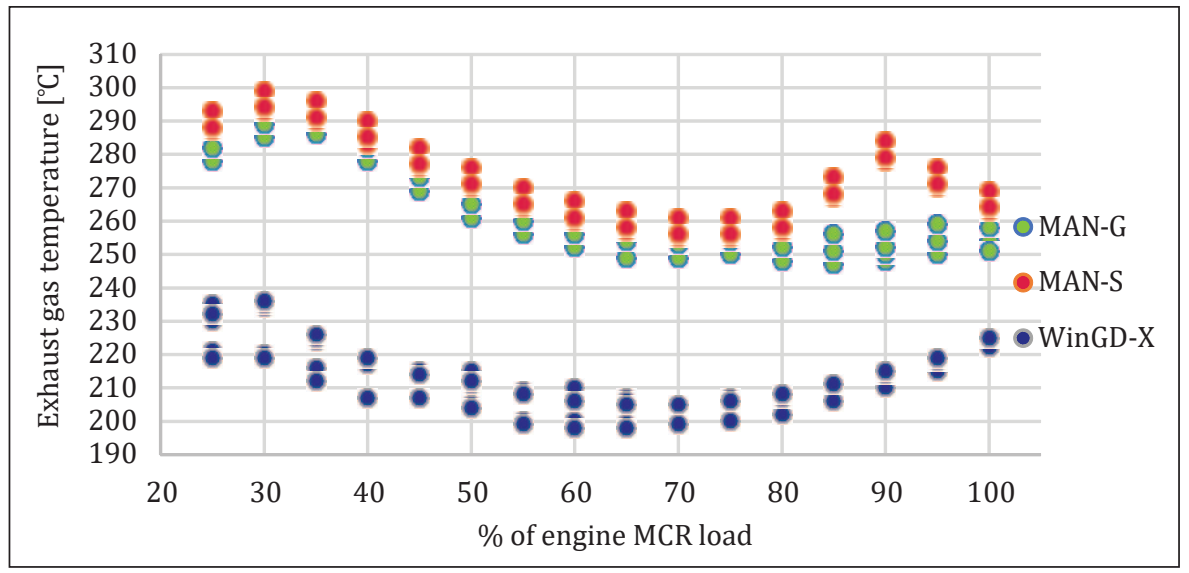

Fig. 11 Temperature of exhaust gas of all available LNG-fuelled low-speed engines in the function of engine load [own study] 


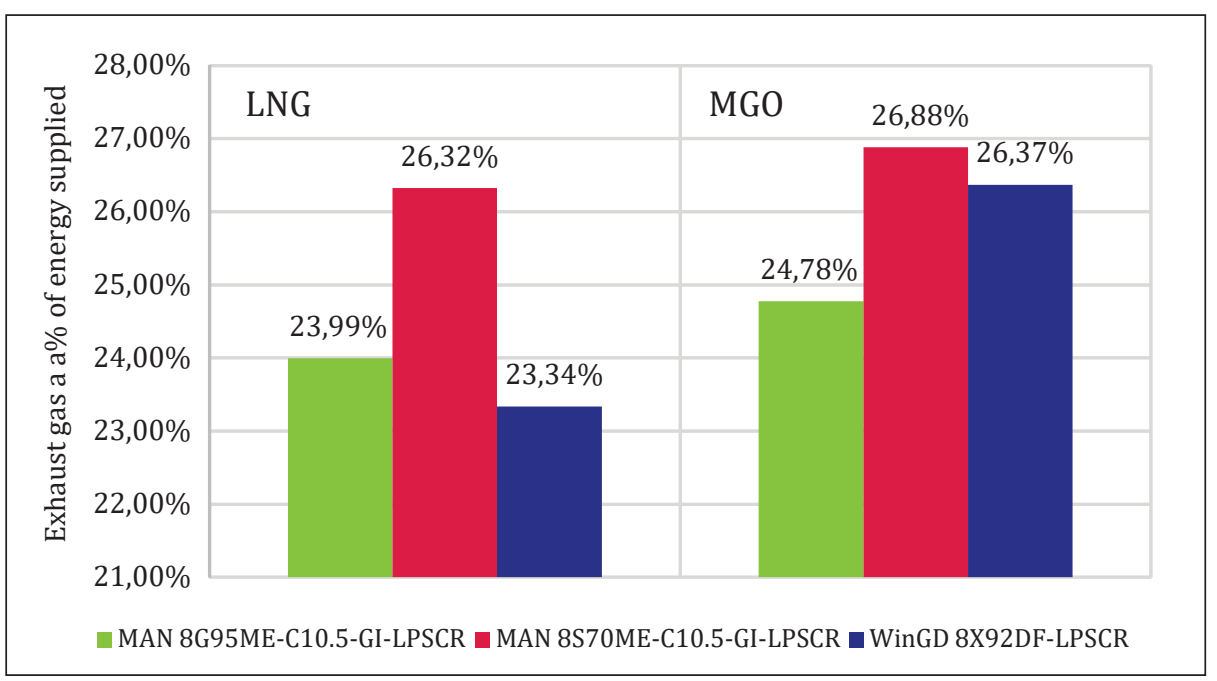

Fig. 12 Exhaust gas waste heat as a \% total energy supplied in fuel [own study]

- The temperature of the exhaust gas in LNG- and MGOfuelled MAN engines assumes the highest values in the range $25 \div 35 \%$ of the MCR load, while the lowest is for $65 \div 75 \%$ (S-type), and both $65 \div 70 \%$ and $80 \div 90 \%$ (G-type). The difference between the extreme values reaches $35 \div 39^{\circ} \mathrm{C}$.

- The temperature of the exhaust gas in LNG-fuelled WinGD low-speed engines assumes the highest values in the range $25 \div 35 \%$ of the MCR load, while the lowest is for $65 \div 80 \%$. The difference between the extreme values reaches $29 \div 32{ }^{\circ} \mathrm{C}$.

Percentage share of exhaust gas waste heat from selected dual-fuel low-speed engines operating in maximum continuous load under ISO ambient conditions in total energy supplied in fuel was presented in Fig. 12.

- The temperature of the exhaust gas in MGO-fuelled WinGD low-speed engines assumes the highest values at the MCR-load point, while the lowest is for $60 \div 70 \%$. The difference between the extreme values reaches $22 \div 25^{\circ} \mathrm{C}$.

- Dual-fuel MAN engines maintain the same overall efficiency (and the sum of heat losses) in both LNG and MGO modes, but the silghtly lower temperature of the exhaust gas in the LNG mode reduces the amount of exhaust gas waste heat by $2.5 \div 3.9 \%$ compared with the MGO mode. Therefore LNG mode is mostly characterised by slightly larger share of amount of scavenge air waste heat in the sum of heat losses than MGO mode.

- The amounts of exhaust gas waste heat from LNG-fuelled WinGD engines is lower by $19.1 \div 19.6 \%$ in comparison with MGO mode. Besides the above-mentioned lower temperature and flow of the exhaust gas, it results from significantly lower total heat losses $(4.2 \div 4.5 \%$ in favour of LNG).

LPSCR is a Tier III-compliant system allowing the maximising of exhaust-gas waste-heat recovery. Its investment costs are up to $15 \%$ lower than its high-pressure (HPSCR) variant. In addition, it affords the possibility to assemble the reactor in a convenient location outside the engine room, and thus reduces the volume of its compartments.

\section{Estimation of amounts of exhaust gas waste heat from dual-fuel low-speed marine main engines equipped with Tier III-compliant LPSCR}

Exhaust gas waste heat, besides non-recoverable and negligibly small radiation loss, is the only process whose amount is not directly stated in manufacturers' catalogues, nor in the files generated by computer-aided engine selection software. In order to explore the possibilities of electricity generation in recovery generation units, or to perform heat balance, exhaust gas waste heat should be estimated according to the formula (3) on the basis of the known flow, temperature, and specific heat [20]. This task requires obtaining and processing a considerable amount of data. Therefore it became necessary to establish readymade formulae which would make it possible to estimate the exhaust gas waste heat for the full range of engine brake power with sufficient accuracy.

A reference list of all available dual-fuel low-speed engines equipped with Tier III-compliant LPSCR was complied for this purpose, on which basic technical parameters under ISO ambient conditions in the LNG and MGO modes were included. This constitutes a guarantee of data reliability and a representative sample. Among the engine technical parameters, the reference list includes those which in a logical and functional way are connected with exhaust-gas waste heat, i.e. engine brake power $P_{B}$ and the corresponding values of flow and temperature.

Dependencies between engine brake power and exhaust gas waste heat were determined separately for all types of available low-speed engines in the LNG and MGO modes. The following regression models were used for the given engines: MAN G-type (Fig. 13-14) and WinGD X-type (Fig. 17-18) - power, MAN S-type (Fig. 15-16) - linear. 


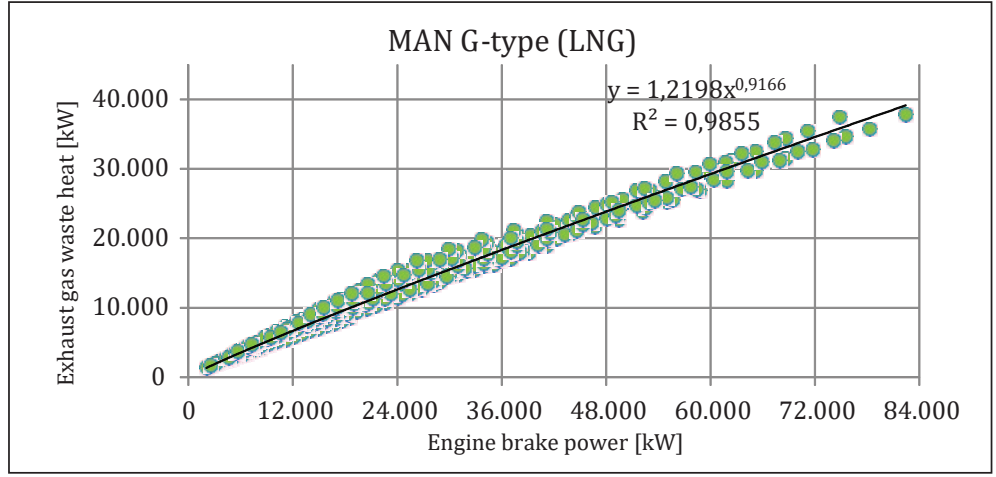

Fig. 13 Exhaust gas waste heat as a function of engine brake power, own study on basis [13]

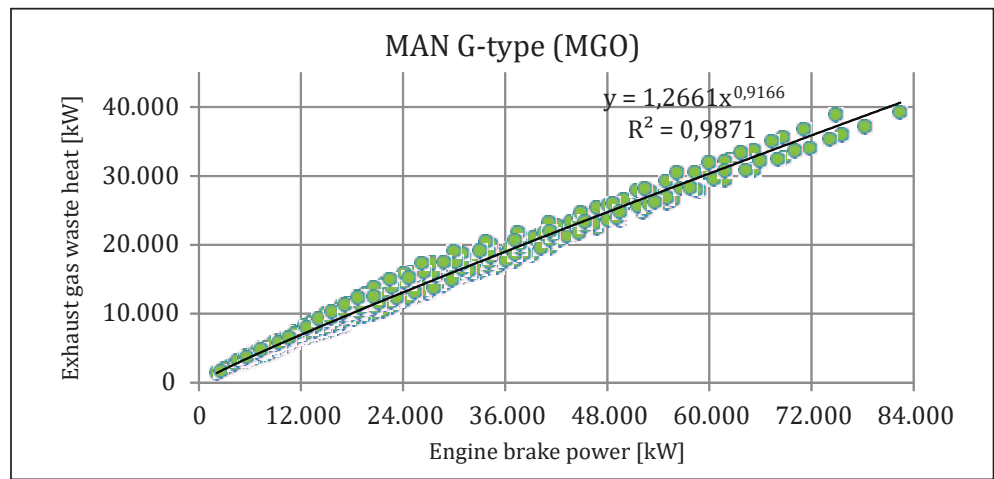

Fig. 14 Exhaust gas waste heat as a function of engine brake power, own study on basis [13]

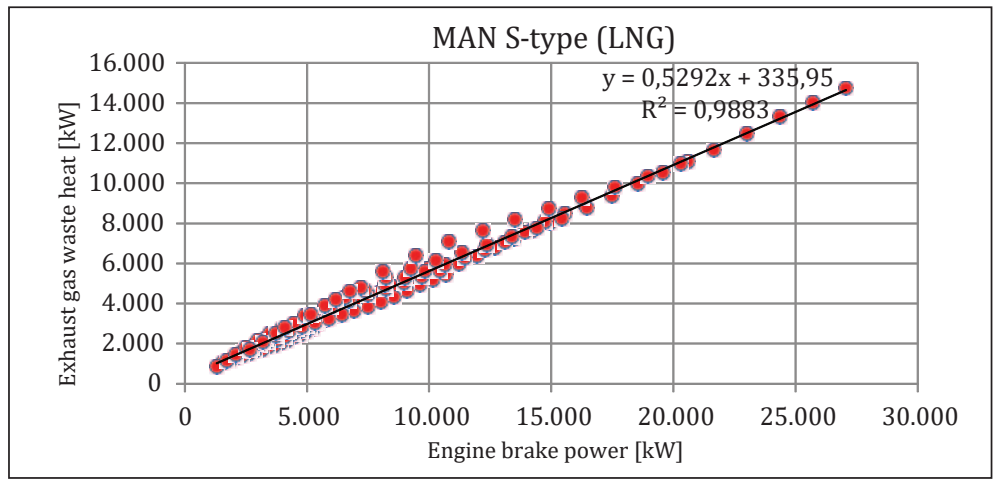

Fig. 15 Exhaust gas waste heat as a function of engine brake power, own study on basis [13]

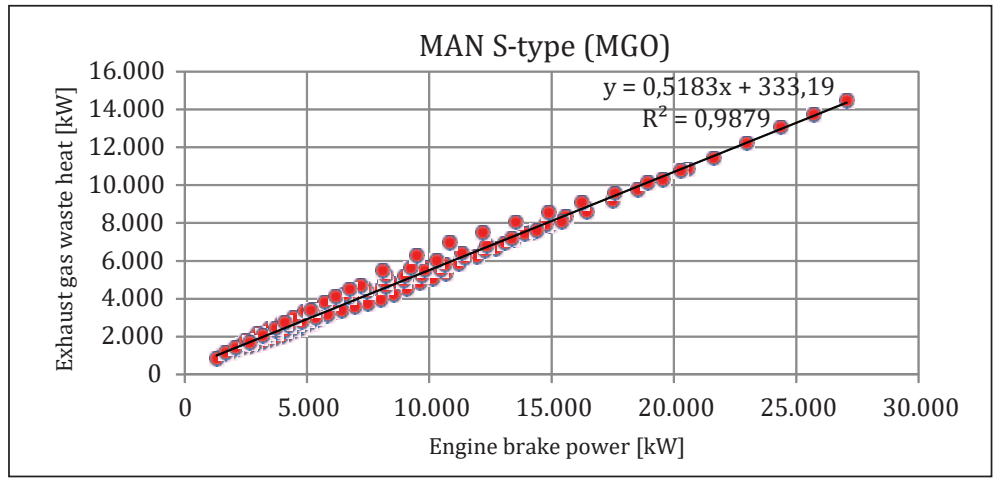

Fig. 16 Exhaust gas waste heat as a function of engine brake power, own study on basis [13] 


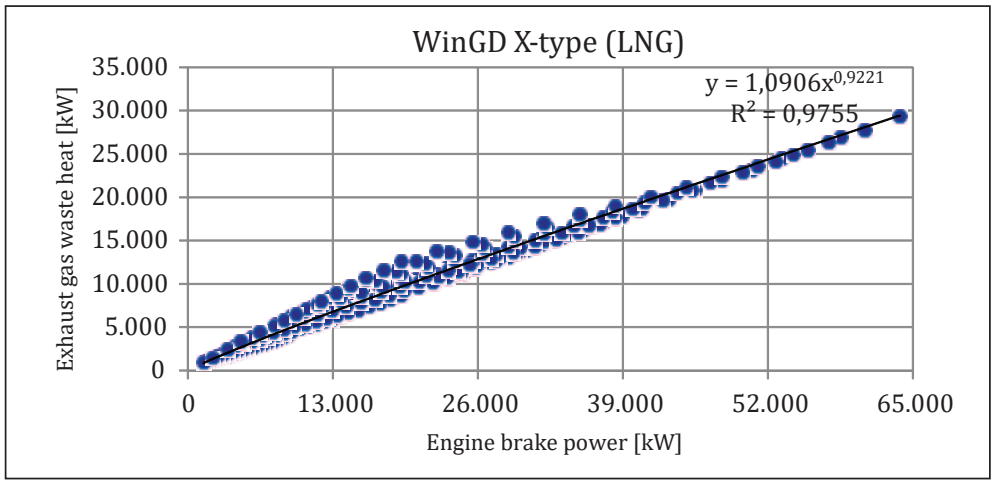

Fig. 17 Exhaust gas waste heat as a function of engine brake power, own study on basis [18]

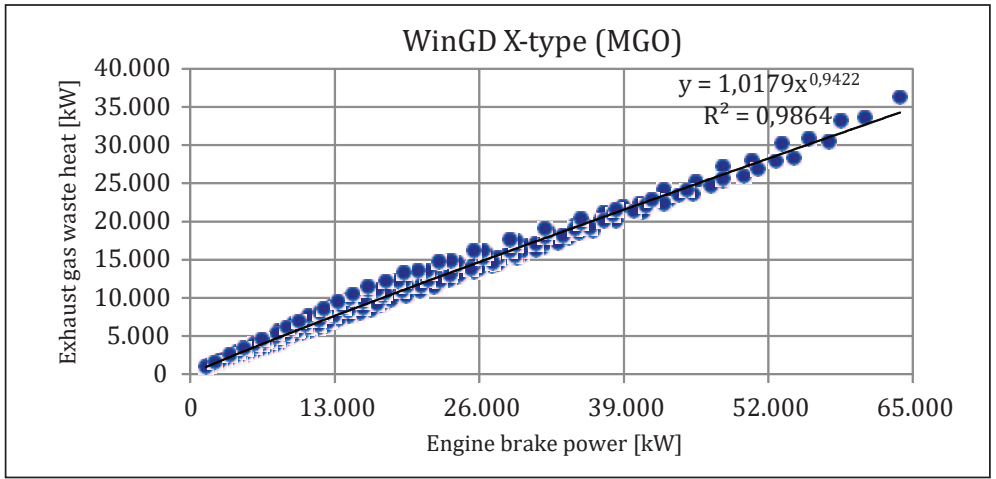

Fig. 18 Exhaust gas waste heat as a function of engine brake power, own study on basis [18]

The least-square method was used in each case. The following formulae were obtained as a result of calculations:

- MAN G-type $\rightarrow$ LNG mode $\left(\mathrm{R}^{2}=0,9855\right):$

$$
\dot{Q}_{g}=1,2198 \cdot P_{B}^{0,9166}
$$

- MAN G-type $\rightarrow$ MGO mode $\left(\mathrm{R}^{2}=0,9871\right):$

$$
\dot{Q}_{g}=1,2661 \cdot P_{B}^{0,9166}
$$

- MAN S-type $\rightarrow$ LNG mode $\left(\mathrm{R}^{2}=0,9883\right):$

$$
\dot{Q}_{g}=0,5292 \cdot P_{B}+335,95
$$

- MAN S-type $\rightarrow$ MGO mode $\left(\mathrm{R}^{2}=0,9879\right):$

$$
\dot{Q}_{g}=0,5183 \cdot P_{B}+333,19
$$

- WinGD X-type $\rightarrow$ LNG mode $\left(\mathrm{R}^{2}=0,9755\right):$

$$
\dot{Q}_{g}=1,0906 \cdot P_{B}^{0,9221}
$$

- WinGD X-type $\rightarrow$ MGO mode $\left(\mathrm{R}^{2}=0,9864\right)$ :

$$
\dot{Q}_{g}=1,0179 \cdot P_{B}^{0,9422}
$$

It should be noted that the determination coefficient reaches the very high values $R^{2}=0,9755 \div 0,9883$, which indicates a strong correlation and fit of the appropriate regression model. Moreover, the established formulae make it possible to apply them with a high probability that the preliminary calculations will be sufficiently close to their results for accurate verification at the detailed design stage.

\section{Conclusions}

The undertaken analysis allowed the conclusion that exhaust gas was the largest carrier of waste energy suitable for effective recovery. In aiming for minimising the value of the IMO energy-efficiency coefficients, it should be mostly used for electricity generation in recovery generator units selected for given main engine brake power.

The results of the calculations contained in Tab. 5-6 indicates that engines equipped with LPSCR are characterised by the highest temperature of exhaust gas and the largest amount of exhaust gas waste heat. Moreover, in comparison with its high-pressure variant, LPSCR is distinguished by lower investment costs and the possibility to assemble reactors in a convenient place outside engine rooms. This increases the economic value of waste heat recovery, and promotes the optimum use of space inside hull.

The amount of exhaust gas waste heat in the LNG mode is lower than in the MGO mode, due to the lower flow and temperature values of exhaust gas. These differences ranges from $2.5 \div 3.9 \%$ for MAN engines to $19.1 \div 19.6 \%$ for WinGD engines. 
The very high values of the $\mathrm{R}^{2}$ coefficient confirm that the formulae determined by the least-square method can be useful for the prediction of exhaust gas waste heat at the preliminary design stage. It provides a basis for the selection of an appropriate waste heat recovery system configuration for any type of engine equipped with LPSCR.

Funding: The research presented in the manuscript did not receive any external funding.

Author Contributions: The research presented in the manuscript has been prepared entirely by the assigned author Piotr Kamil Korlak. No other authors have contributed to this research.

\section{References}

[1] BAZARI Z., MARPOL Annex VI Chapter 4 - Energy efficiency regulations, National Workshop on Ratification and Implementation of MARPOL Annex VI for Egypt, 25.11.2020, pp. 3-19, available at: https://www.rempec.org/en/ knowledge-centre/online-catalogue/5-zb-l03-marpolannex-vi-chapter-4-final.pdf (last acces: 28.02.2021)

[2] CLAUSEN N.B., Tier III NOX emission reduction technologies EGR and SCR, 11/2015, pp. 4-15, available at: https:// marine.man-es.com/docs/librariesprovider6/marketingpublications/japanese-seminar-2018-english/02-meetingeedi-future-ghg-challenges.pdf (last access: 28.02.2021)

[3] DELTAMARIN, Future fuel options and emission control, available at: https://deltamarin.com/current-challenges/ future-fuel-options-and-emission-control/ (last access: 28.02.2021)

[4] DNV-GL, Energy Efficiency Existing Ship Index, available at: https://www.dnvgl.com/maritime/insights/topics/eexi/ index.html (last access: 28.02.2021)

[5] GIERNALCZYK M., LUS M., Wpływ utylizacji ciepła odpadowego silnika głównego na wielkość projektowego współczynnika efektywności energetycznej EEDI na przykładzie wybranego kontenerowca, Czasopismo Logistyka 4/2015, pp. 6-8.

[6] KORLAK P., Dobór głównego układu napędowego kontenerowca typu ultra-large o pojemności ładunkowej 19000 TEU, Praca dyplomowa inżynierska, Wydział Mechaniczno-Elektryczny, Akademia Marynarki Wojennej w Gdyni, Gdynia 2017, pp. 62-69.
[7] LIBERACKI R., Niekonwencjonalne metody odzysku ciepła odpadowego na statkach, Journal of Polish CIMEEAC, Vol. 14 , No. $1 / 13$, pp. 1-2.

[8] MAN DIESEL \& TURBO A/S, Costs and benefits on LNG as a ship fuel for container vessels, Copenhagen 2017, pp. 5-6.

[9] MAN DIESEL \& TURBO A/S, Emission project guide - MAN $B \& W$ two-stroke marine engines, Copenhagen 2017, pp. 1317 and 57-67.

[10] MAN DIESEL \& TURBO A/S, Waste Heat Recovery System (WHRS) for reduction of fuel consumption, emissions and EEDI, Copenhagen 2017, pp. 5-9.

[11] MAN DIESEL \& TURBO A/S, New PrimeServ Academy Technical Seminar, Pireaus, 22-23.10.2015, pp. 10-13.

[12] MAN DIESEL \& TURBO A/S, Tier III two stroke technology, Copenhagen 2017, pp. 6-11.

[13] MAN Energy Solutions A/S, CEAS Engine Data Reports for: S35ME-C9.7-GI, S40ME-C9.5-GI, G45ME-C9.5-GI, S46MEC8.6-GI, S50ME-C8.5-GI, G50ME-C9.6-GI, S50ME-C9.7-GI, S60ME-C10.5-GI, S65ME-C8.6-GI, G60ME-C10.5-GI, G70MEC10.5-GI, S70ME-C10.5-GI, G70ME-C10.5-GI, S80ME-C9.5-GI, G80ME-C10.5-GI, S90ME-C10.5-GI, G90ME-C10.5-GI, G95MEC10.5-GI, obtained from MAN CEAS Engine Calculation online application available at: https://www.man-es.com/marine/ products/planning-tools-and-downloads/ceas-enginecalculations (last access: 28.02.2021)

[14] MAN Energy Solutions A/S, Marine engine programme 2020, Copenhagen 2020, pp. 14-15.

[15] MERKISZ J., FUC P., LIJEWSKI P., ZIÓŁKOWSKI A. and WOJCIECHOWSKI K., The analysis of exhaust gas thermal energy recovery through a TEG generator in city traffic conditions reproduced on a dynamic engine test bed, Journal of Electronic Materials, Vol. 44, No. 6/2015, p. 10.

[16] MERKISZ J., PIASECZNY L., Możliwości obniżenia niekorzystnego wpływu recyrkulacji spalin na sprawność ogólnq okrętowego silnika napędu głównego, Archiwum Motoryzacji, 3/2006, pp. 1-6.

[17] SCHNEITER D., Tier III programme - status and outlook, Lincensees' Conference 2015, Interlaken 06-09.09.2015, pp. 8-17.

[18] Winterthur Gas \& Diesel Ltd., General Technical Data for: X40DF, X52DF, X62DF, X72DF, X82DF, X92DF, obtained from GTD 2.12.0.1. desktop application (last access 28.02.2021)

[19] Winterthur Gas \& Diesel Ltd., Selective Catalytic Reduction FAQ, Winterthur 2018, pp. 4-9.

[20] WITKOWSKI K., PIOTROWSKI I., Okrętowe silniki spalinowe, Trademar, Gdynia 2013, pp. 103-109. 